\title{
Prevalence and Influencing Factors of Obesity in Elementary School Children
}

\author{
Soepardi Soedibjo, Mulyadi M Djer, Agus Firmansyah \\ (Department of Child Health, Medical School, University of Indonesia/ \\ Cipto Mangunkusumo Hospital, Jakarta)
}

\begin{abstract}
An observational, cross sectional study was conducted on elementary school students in Central Jakarta between May and October 1997. This preliminary study aimed to determine the prevalence and influencing factors of obesity in elementary school students. From 488 students studied, 47 were obese. The prevalence rate in this study was $9.6 \%$, with boys twice as much as girls. Factors that influenced the incidence of obesity were: (1) age, (2) time of introduction of solid food during infancy, (3) eating habit, (4) calorie intake, and (5) physical activities. There were two factors that increased the incidence of obesity namely: (1) obesity of parents, and (2) birth weight Environmental factors that increased the incidence of obesity were: (1) parent's occupation and (2) family income. Laboratory findings associated with obesity were: (1) increase blood cholesterol concentration, (2) increase blood triglyceride concentration, (3) decreased HDL cholesterol concentration, and (4) increased LDL cholesterol concentration. We conclude that the prevalence rate of obesity obtained in this study was higher compared with the previous studies, and that obesity in school children is influenced by many factors. [Paediatr Indones 1998; 38:193-204]
\end{abstract}

\section{Introduction}

Obesity constitutes overnourished problems often encountered in well developed countries and is a clinical problem that is hard to deal with, ${ }^{1-3}$ because of its multifactorial etiology. ${ }^{4-6}$ There are changes in lifestyle and eating habits due to industrialization in our country, ${ }^{7-9}$ that brings to a higher income that increases excessive food consumption. ${ }^{9,10}$ On the other hand, the increasing varieties of fast food or canned 
food, makes people neglect the well balanced diet until obesity develops. ${ }^{911}$ Obesity is predicted to be an arising problem as the result of ongoing changes from developing to industrial community." Unfortunately publication about obesity prevalence in children especially in school-age children in our country is very limited. ${ }^{4,9,12-13}$

Obesity is a condition in which the nutritional status above normal, characterized by the accumulation of excessive fat. ${ }^{1-3}$ It usually occurs if the energy intake in excess to the energy expenditure, ${ }^{14-16}$ besides theory related with fat cell development. ${ }^{17-19}$ Lately obesity has been associated with leptin, a protein produced by fat cell, that has important role in fat metabolism. Its inappropriate concentration will increase food intake and decrease energy expenditure that at the end will cause obesity. ${ }^{20,21}$ There are other important factors such as genetic and environment that will easily make someone obese. ${ }^{22}$ The aim of this study was to determine the prevalence and influencing factors of obesity in elementary school students.

\section{Methods}

This was an observational study with cross sectional design, ${ }^{23}$ conducted in SDN 7 and 8 Kenari Jakarta Pusat, from May to October 1997. All students of the two schools were subjected for the study, except those who refused to be enrolled and those with certain diseases or syndromes.

The study comprised 3 parts. The first part was to determine the prevalence of obesity by anthropometric measurements based on weight for height index. ${ }^{24}$ The second was to determine the characteristics of obese children, energy intake, genetic factors, environmental factors, and laboratory findings (hemoglobin, cholesterol, triglyceride, HDL and LDL cholesterol). 'The third part was to compare some of the characteristics between the obese and non-obese children. Association between risk factors and obesity was performed by bivariat analysis. All relevant data were collected and put into the computer program (Epi-info 6.0 version). For analysis $\mathrm{p}<0.05$ was considered significant. Odds ratio (OR) with $95 \%$ confidence intervals was supplied when relevant.

\section{Results}

\section{Prevalence and characteristics of obese children}

Four hundred eighty eight students were registered in SDN 7 and 8 Kenari Jakarta Pusat for 1996/1997 school term, 47 of them were obese. The prevalence rate of obesity was $9.6 \%$, with boys were twice as many as girls. Table 1 shows the age and sex distribution of the study subjects. There was no significant difference subjects in terms of sex and age group. 
Table 1. Age and sex distribution of study subjects

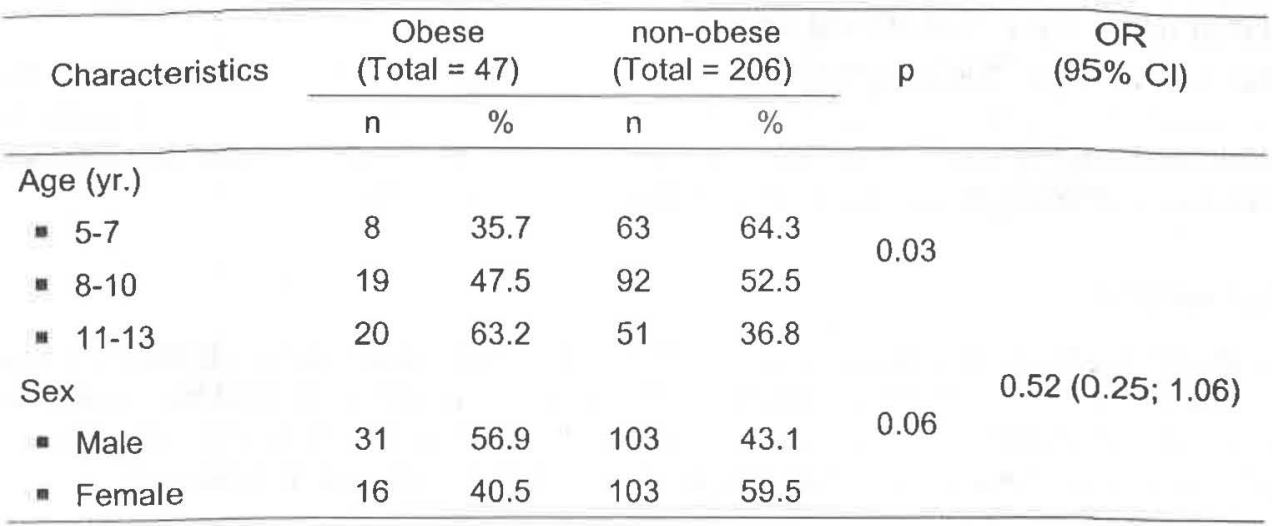

Table 2. Distribution of obese patients by weight for height index

\begin{tabular}{ccrcrr}
\hline \multirow{2}{*}{$\begin{array}{c}\text { Age group } \\
\text { (year) }\end{array}$} & \multicolumn{3}{c}{ Weight for height index (\%) } & \multirow{2}{*}{ Total } \\
\cline { 2 - 5 } & Mean (SD) & \multicolumn{1}{c}{$\mathrm{n}$} & Mean $(\mathrm{SD})$ & \multicolumn{1}{c}{$\mathrm{n}$} & \\
\cline { 2 - 5 } " $5-7$ & $130.5(12.0)$ & 4 & $166.2(45.7)$ & 4 & 8 \\
" $8-10$ & $147.9(22.7)$ & 12 & $130.7(10.9)$ & 7 & 19 \\
$=11-13$ & $138.7(10.3)$ & 15 & $141.9(14.9)$ & 5 & 20 \\
\hline Total & $141.2(17.0)$ & 31 & $143.1(27.2)$ & 16 & 47 \\
\hline
\end{tabular}

Table 3. Distribution of obese patients by degree of obesity

\begin{tabular}{|c|c|c|c|c|c|c|c|c|c|c|}
\hline \multirow{3}{*}{$\begin{array}{r}\text { Age group } \\
\text { (year) }\end{array}$} & \multicolumn{8}{|c|}{ Degree of obesity } & \multicolumn{2}{|c|}{ Total } \\
\hline & \multicolumn{2}{|c|}{ Mild } & \multicolumn{2}{|c|}{ Moderate } & \multicolumn{2}{|c|}{ Severe } & \multicolumn{2}{|c|}{ Super } & \multirow[b]{2}{*}{$n$} & \multirow[b]{2}{*}{$\%$} \\
\hline & $\mathrm{n}$ & $\%$ & $n$ & $\%$ & $n$ & $\%$ & $n$ & $\%$ & & \\
\hline $5-7$ & 5 & 62.5 & 1 & 12.5 & 1 & 12.5 & 1 & 12.5 & 8 & 17 \\
\hline $8-10$ & 9 & 47.4 & 4 & 21.1 & 5 & 26.3 & 1 & 5.3 & 19 & 40.4 \\
\hline $11-13$ & 6 & 30.0 & 12 & 60.0 & 2 & 10.0 & 0 & 0.0 & 20 & 42.6 \\
\hline Total & 20 & 42.6 & 17 & 36.2 & 8 & 17.0 & 2 & 4.3 & 47 & 100.0 \\
\hline
\end{tabular}


Table 2 shows the weight for height index in female and in male obese subjects by age group, while Table 3 shows the distribution of degree of obesity by age group. It shows that most obese was of mild degree.

Table 3 shows that the moderate degree of obesity increased with age, whereas the number of cases decreased with age in the super obese. Most of the obese student in this study did not have any other accompanying disease and did not have any interaction problems with family members or playmates (data not shown).

\section{Energy intake}

In this study, both obese and non-obese children received milk formula before the age of four months, and most of them received breast milk and formula until two years old (Table 4). Statistical test did not show association between this pattern and obesity. Table 4 also showed obese children among those who received breast milk only.

Early introduction of solid food was significantly more seen in obese children than in non-obese ones. The same was found with eating habit, where most obese children had bad habits such as eating between meals and while watching television than did non-obese children. Obese children had significantly more calorie intake beyond recommended value than non-obese. Children with high calorie intake had 2.21 higher chance for becoming obese than those with calorie intake in accordance with the recommended value. On the other hand, relationship between obesity and protein intake was not clear (Table 5). Table 5 also showed the association between obesity and activity; the less active the child, the more likely he or she became obese. This study revealed a higher energy intake in less active children, but the difference was not significant (Table not presented). Most obese children realized that he or she was obese, and had had tried to lose weight but all had failed.

\section{Genetic factors}

This study revealed that most obese children had obese parents or at least one of the parents was obese; this association was statistically significant. The same thing went with birth weight, where most of obese children were born with birth weight of more than 4000 grams. Statistical analysis showed a significant correlation. On the other hand the relation of twins and obesity was not significant (Table 6).

\section{Family environment}

Obesity had a significant association with parent's occupation and family income, but no association was found between obesity and parent's education level (Table 7). 
Table 5. Association between obesity and feeding pattern and eating habit

\begin{tabular}{|c|c|c|c|c|c|}
\hline \multirow[t]{2}{*}{ Characteristics } & \multicolumn{2}{|c|}{$\begin{array}{c}\text { Obese } \\
(\text { Total }=47)\end{array}$} & \multicolumn{2}{|c|}{$\begin{array}{c}\text { Non-obese } \\
(\text { Total }=206)\end{array}$} & \multirow[t]{2}{*}{$p$} \\
\hline & $n$ & $\%$ & $\mathrm{n}$ & $\%$ & \\
\hline \multicolumn{6}{|l|}{ Feeding pattern during infancy } \\
\hline - Only milk formula until 2 years & 2 & 59.7 & 6 & 40.3 & \multirow{4}{*}{0.95} \\
\hline $\begin{array}{l}\text { - Milk formula before } 4 \text { months + } \\
\text { breast milk }\end{array}$ & 19 & 50.7 & 81 & 49.3 & \\
\hline $\begin{array}{l}\text { - Milk formula after } 4 \text { months + } \\
\text { breast milk }\end{array}$ & 11 & 47.2 & 54 & 52.8 & \\
\hline - Only breast milk until 2 years & 15 & 50.2 & 65 & 49.8 & \\
\hline \multicolumn{6}{|l|}{ Solid food introduction } \\
\hline - Early & 24 & 84.7 & 19 & 15.3 & \multirow{3}{*}{$<0.0001$} \\
\hline - Proper & 19 & 34.1 & 161 & 65.9 & \\
\hline - Late & 4 & 40.3 & 26 & 59.7 & \\
\hline \multicolumn{6}{|l|}{ Eating habit } \\
\hline " Bad & 31 & 73.5 & 49 & 26.5 & \multirow{3}{*}{$<0,0001$} \\
\hline - Fair & 11 & 29.5 & 115 & 70.5 & \\
\hline - Good & 5 & 34.2 & 42 & 65.8 & \\
\hline
\end{tabular}

\section{Laboratory findings}

Obese children had a significantly higher cholesterol concentration than non-obese children. Likewise of triglyceride and LDL cholesterol concentration in obese children were high, but HDL cholesterol concentration was low. The difference in hemoglobin concentration between obese and non obese children was not significant (Table 8).

\section{Discussion}

The prevalence rate of obesity in this study $(9.6 \%)$ was higher than Satoto's ${ }^{12}$ study which involved 5000 elementary school students. This was also higher compared with reports of Samsudin, ${ }^{7.9}$ Nasar, ${ }^{4}$ and Hambali, ${ }^{3}$ as well as with reports from Thailand, ${ }^{7 . \prime \prime}$ and was almost as high as in The United States and Australia. ${ }^{7-9,25-27}$ Although the target population for this study did not represent the real population, it looked like that obesity started to dominate overnourished problems, that need special attention. ${ }^{9}$ 
Table. 6. Association between calorie intake, protein, and physical activities with obesity

\begin{tabular}{|c|c|c|c|c|c|c|}
\hline \multirow[t]{2}{*}{ Characteristics } & \multicolumn{2}{|c|}{$\begin{array}{c}\text { Obese } \\
(\text { Total }=47)\end{array}$} & \multicolumn{2}{|c|}{$\begin{array}{l}\text { Non-obese } \\
(\text { Total }=206)\end{array}$} & \multirow[t]{2}{*}{$p$} & \multirow{2}{*}{$\begin{array}{c}\text { OR } \\
(95 \% \mathrm{Cl})\end{array}$} \\
\hline & $n$ & $\%$ & $\mathrm{n}$ & $\%$ & & \\
\hline \multicolumn{7}{|l|}{ High calorie intake } \\
\hline " Yes & 16 & 64.3 & 39 & 35.7 & \multirow[t]{2}{*}{0.038} & \multirow{2}{*}{$\begin{array}{c}2.21 \\
(1.03 ; 4.71)\end{array}$} \\
\hline - No & 31 & 44.9 & 167 & 55.1 & & \\
\hline \multicolumn{7}{|l|}{ High prótein intake } \\
\hline - Yes & 28 & 55.1 & 100 & 44.9 & \multirow[t]{2}{*}{0.23} & \multirow{2}{*}{$\begin{array}{c}1.56 \\
(0.78 ; 3.14)\end{array}$} \\
\hline$=$ No & 19 & 44 & 106 & 56 & & \\
\hline \multicolumn{7}{|l|}{ Physical activity } \\
\hline - Less active & 36 & 62 & 97 & 38 & \multirow{3}{*}{0.0012} & \\
\hline - Fair & 10 & 31.6 & 95 & 68.4 & & \\
\hline - Very active & 1 & 23.6 & 14 & 76.4 & & \\
\hline
\end{tabular}

Table 7. Association of obesity and obese parents and birth weight

\begin{tabular}{lccccc} 
Characteristics & $\begin{array}{c}\text { Obese } \\
(\text { Total }=47)\end{array}$ & $\begin{array}{c}\text { Non-obese } \\
(\text { Total = 206) }\end{array}$ & p & OR $(95 \% \mathrm{Cl})$ \\
\cline { 2 - 3 } & $\mathrm{n}$ & $\%$ & $\mathrm{n}$ & $\%$ &
\end{tabular}

Obese parents

$\begin{array}{lllll}\text { * Both of parents obese } & 3 & 86.5 & 2 & 13.5\end{array}$

* One of parents obese $23 \quad 72.1 \quad 39 \quad 27.9$

$\begin{array}{lllll}\text { - Both of parents } \quad 21 & 35.8 & 165 & 64.2\end{array}$ non-obese

Birth weight (gram)

$0 \quad 6,0(1.31 ; 28.43)$

$\begin{array}{lllll}\text { - }<4.000 & 42 & 47.7 & 202 & 52.3 \\ \text { " }>4.000 & 5 & 84.8 & 5 & 15.2\end{array}$


Table 8. Association between obesity and parent's education, occupation, and family income

\begin{tabular}{|c|c|c|c|c|c|c|}
\hline \multirow[t]{2}{*}{ Characteristics } & \multicolumn{2}{|c|}{$\begin{array}{c}\text { Obese } \\
(\text { Total }=47)^{\prime}\end{array}$} & \multicolumn{2}{|c|}{$\begin{array}{c}\text { Non-obese } \\
(\text { Total }=206)\end{array}$} & \multirow[t]{2}{*}{$\mathrm{p}$} & \multirow[t]{2}{*}{$\begin{array}{c}\text { OR } \\
(95 \% \mathrm{Cl})\end{array}$} \\
\hline & $\mathrm{n}$ & $\%$ & $\mathrm{n}$ & $\%$ & & \\
\hline \multicolumn{7}{|l|}{ Parent's education } \\
\hline $\begin{array}{l}\text { - Senior high school or } \\
\text { less }\end{array}$ & 19 & 47.3 & 93 & 52.7 & \multirow[t]{2}{*}{0.56} & $\begin{array}{c}0.82 \\
(0.41 ; 0.65)\end{array}$ \\
\hline - Academy / university & 28 & 52.1 & 113 & 47.9 & & \\
\hline \multicolumn{7}{|l|}{ Parent's occupation } \\
\hline - Low & 10 & 37.6 & 73 & 62.4 & \multirow{3}{*}{0.0005} & \\
\hline - Moderate & 32 & 51.7 & 131 & 48.3 & & \\
\hline \# High & 5 & 91.4 & 2 & 8.6 & & \\
\hline \multicolumn{7}{|l|}{ Family income } \\
\hline - Low & 13 & 39.3 & 88 & 60.7 & \multirow{3}{*}{0.015} & \\
\hline - Moderate & 31 & 54 & 116 & 46 & & \\
\hline - High & 3 & 86.3 & 2 & 13.7 & & \\
\hline
\end{tabular}

Table 9. Comparison of hemoglobin level and lipid profile between obese and non-obese children

\begin{tabular}{lrrr}
\hline \multicolumn{1}{c}{ Parameter } & \multicolumn{1}{c}{ Obese } & Non-obese & \multicolumn{1}{c}{$\mathrm{p}$} \\
\cline { 2 - 3 } & \multicolumn{1}{c}{ Mean (SD) } & \multicolumn{1}{c}{ Mean (SD) } & \\
\hline Hemoglobin $(\mathrm{g} / \mathrm{dl})$ & $13.3(1.2)$ & $13.0(1.2)$ & 0.08 \\
Cholesterol $(\mathrm{mg} / \mathrm{dl})$ & $180.3(26.4)$ & $169.4(31.4)$ & 0.006 \\
Triglyceride $(\mathrm{mg} / \mathrm{dl})$ & $120.7(59.0)$ & $91.8(42.6)$ & 0.0007 \\
HDL $(\mathrm{mg} / \mathrm{di})$ & $43.3(11.4)$ & $48.6(11.5)$ & 0.004 \\
LDL $(\mathrm{mg} / \mathrm{dl})$ & $113.3(22.9)$ & $102.4(27.5)$ & 0,002 \\
\hline
\end{tabular}

The prevalence rate of obesity in boys was higher than in girls, in contrast with other reports; ${ }^{4,7-9,13}$ however, the difference was not significant (Table 1). Most obese 
were between 11-13 years, followed by 8-10 years and 5-7 years age group. It appeared that the percentage of obesity increased with the increasing age. This was similar to that reported by others, ${ }^{79,13.24}$ This was in accordance with the pathogenesis and pathophysiology of obesity, ${ }^{4,15}$ which is associated with hormonal influence and with the child ability to consume. ${ }^{7.8}$ Most obesity found was of mild degree, followed by moderate, severe and super. Similar with reports in the literature, the moderate obesity tends to increase with increasing age. However super obesity tends to decrease when the child gets older, because the child will have difficulties in socialization, so the child will try to lose weight. ${ }^{7.8}$

According to the literature, obesity in a child has less impacts than in adult.t.8 Obesity in adult will generate into health problems such as airway and cardiovascular diseases. ${ }^{29,30-32}$ In this study, most of the student did not have any accompanying disease. Samsudin stated that severe obesity was associated with the possibility of accompanying airway, hypertension, dermatitis eczema.7,8,33 Two out of 47 children with super obesity did not have any accompanying disease. Whereas Moussa ${ }^{34}$ found a positive association between systolic and diastolic blood pressures with obesity. This is very likely due to racial difference besides different measuring technique.

It is believed that breast milk or milk formula introduction in infancy influences the development of obesity, ${ }^{35-37}$ Breast milk composition is sufficient for the child 's growth and development on the one hand, and can prevent obesity on the other hand. ${ }^{36}$ Most children enrolled in this study had received milk formula before the age of four months besides breast milk. This study found no significant association between breast milk / milk formula pattern and obesity, which differs from Hambali's report. ${ }^{13}$ This study also revealed that obesity occurred in children who only received breast milk. Obesity due to breast milk is rare, because certain nucleotides will stimulate muscle tissue development so that fat tissue development will decrease. ${ }^{1,37}$

Our data show that most of obese children received solid food early. Statistical test showed a significant correlation between obesity and the pattern. This is in accordance with the literature stating that a child who received solid fooct earlier would have a greater possibility of developing obesity than those who received solid food according to the recommended schedule. ${ }^{7,8,13,38,39}$ Most parents believed that satisfying the baby with solid food was an evidence of love, besides most parents would like to see their babies gaining weight quickly. ${ }^{40}$ This study revealed that the reason for giving solid food early was because the baby had cried out of hunger and this fact was similar to Hambali's finding. ${ }^{13}$

In relation to eating habit, this study revealed that most of obese children had bad eating habit and the difference was significant. Obese children had habits of eating between meals and while watching television, so that the amount of calorie consumed was higher than recommended until they developed into obesity. ${ }^{78,40,41}$ According to the literature children with bad eating tend to develop obesity ${ }^{7,13}$ Several studies conducted in other countries revealed that for every hour of added TV programs, there 
would be a $2 \%$ increase in the obesity prevalence rate. ${ }^{40}$ Besides high calorie fast food like fried chicken, hamburgers or pizza are available everywhere. ${ }^{11}$

From the calorie intake point of view, high calorie intake was found arnongst obese children, the difference was significant, as previously reported. ${ }^{42}$ Samsudin explained that those consuming excessive calorie food for a long time, would become obese. Protein intake did not seem to effect both groups. In the literature it was stated that high protein intake was recommended as a way to modify one's diet in order to lessen the amount of calorie coming from carbohydrate or fat. ${ }^{43}$

Most of obese children realized that he or she was obese, and they had tries to lose weight, but their efforts were not satisfactory. According the literature the success or failure in dealing with obesity, depended on the person's motivation, perseverance and family background. ${ }^{7,8}$ Physical activities have an important role in the occurrence of obesity. Most of the obese children enrolled in this study were less active, and the difference between both groups was significant and supported by literature. ${ }^{44,45}$ Endo $^{44}$ reported that doing excessive along with diet, would reduce body weight and blood cholesterol to bring down the incidence rate of atherosclerosis.

According to Tait $z$ there was a correlation between genetic and obesity. This means that obese parents are very likely to have obese children. In this study there were $6.4 \%$ obese children with both obese parents, while the other $48 \%$ had only one parent obese and $11.3 \%$ came from normal parents. Statistic test showed a significant and this was also supported by the literature. ${ }^{1,2,15}$ Most of obese children were born with their birth weight above 4000 grams. This was commensurate with Taitz's report that obesity was genetically influenced by birth weight. There was no statistic evidence that the incidence of obesity in twins is lower than in normal children. As stated in the literature this is most likely due to the birth weight itself, most of twins were born with a low birth weight. ${ }^{2}$

In relation to family environment, only parents' occupation and family income had correlation with obesity. According to the literature, those two factors influenced family ability to provide excessive food. ${ }^{9}$ Parents' education level had no correlation with the incidence of obesity. No interaction problems were found amongst obese children. ${ }^{7.8}$ The only interaction problems found amongst super obese children was due to their inability to do exercises.

Laboratory findings showed similar hemoglobin concentration between obese and non-obese children. The explanation for this was because both groups consumed high protein food. Lipids concentration such as cholesterol, triglyceride, LDL cholesterol in obese children was higher and this was statistically significant. HDL cholesterol, the only protective lipid in preventing coronary heart disease, ${ }^{46,47}$ was found to be in a very low concentration amongst obese children. Most experts agree that concentration of cholesterol, triglyceride and LDL cholesterol is one of the predisposing factors for coronary heart disease. 
This preliminary study showed the increasing prevalence rate of obesity compared with previous studies. Although most obese children realize their problem and try to deal with it, their efforts are in vain because they do not include every influencing aspects; their efforts are limited to lessen calorie intake. Aside of obese parents, birth weight, introduction of solid food pattern and eating habit are also important factors. That is why, when dealing with obesity all aspects should be considered. A multidisciplinary approach involving by pediatrician, nutritionist and physiotherapist may be needed in some cases. ${ }^{40}$

\section{References}

1. Dietz WH. Childhood and adolescent obesity. In: Walker WA, Watkins JB, eds. Nutrition in pediatrics. Boston: Little Brown and Company; 1985. p. 760-80.

2. Taitz LS, Obesity. In: McLaren DS, Burman D, Belton NR, Williams AT, eds. Textbook of paediatric nutrition. 3rd ed. Edinburgh: Churchill Livingstone; 1991. p. 485-509.

3. Pi-Sunyer FX. Obesity. In: Shils ME, Young VR, eds. Modern nutrition in health and disease. 7 th ed. Philadelphia: Lea and Febiger; 1988. p. 795-816.

4. Nasar SS. Obesitas pada anak: aspek klinis dan pencegahan. In: Samsudin, Nasar SS, Sjarif DR, eds. Masalah gizi ganda dan tumbuh kembang anak. Naskah lengkap Pendidikan Kedokteran Berkelanjutan Ilmu Kesehatan Anak XXXV; Jakarta 11-12 Agustus 1995. Jakarta: Binarupa Aksara; 1995. p. 68-81.

5. Charney E, Goodman HC, McBride M. Childhood antecedents of adult obesity. Do chubby infants beecome obese adults? N Eng Med J Med 1976; 295:6-9.

6. Mossberg HO. 40 year follow-up of overweight children. Lancet 1989; 26:491-3.

7. Samsudin. Obesitas pada anak, penanggulangan dan pencegahannya. Presented at KONIKA Ke-X, Semarang, June 13-17, 1993.

8. Samsudin. Gizi lebih pada anak dan masalahnya. In: Rifai MA, Nontji A, Erwidodo, eds. Risalah widya karya pangan dan gizi V. Jakarta: Lembaga Ilmu Pengetahuan Indonesia; 1994. p. $397-409$.

9. Samsudin. Masalah gizi ganda pada anak: suatu tantangan baru. In: Samsudin, Nasar SS, Sjarif DR, eds. Masalah gizi ganda dan tumbuh kembang anak. Naskah lengkap Pendidikan Kedokteran Berkelanjutan Ilmu Kesehatan Anak XXXV; Jakarta 11-12 Agustus 1995. Jakarta: Binarupa Aksara; 1995. p. 1-11.

10. Kartasasmita G. Masyarakat Indonesia di tahun 2000: tantangan bagi pendidikan tinggi kesehatan. Presented at Dies Natalis ke-48 Fakultas Kedokteran Universitas Indonesia, Jakarta, April 4, 1997.

11. Fong H. Fast food. In: Samsudin, Nasar SS, Sjarif DR, eds. Masalah gizi ganda dan tumbuh kembang anak. Naskah lengkap Pendidikan Kedoktenan Berkelanjutan Ilmu Kesehatan Anak XXXV; Jakarta 11-12 Agustus 1995. Jakarta: Binarupa Aksara; 1995. p. $114-9$

12. Satoto. Komunikasi, informasi dan edukasi (KIE) gizi lebih sebagai bagian dari KIE gizi ganda. In: Rifai MA, Nontji A, Erwidodo, Jalal F, Fardiaz F, Fallah TS, eds. Risalah widya karya pangan dan gizi $V_{\text {; }}$ Jakarta 20-22 April 1993. Jakarta: Lembaga llmu Pengetahuan Indonesia; 1994. p. 562-75. 
13. Hambali SW. Aspek gizi dan lingkungan keluarga pada pasien obesitas di Bagian Ilmu Kesehatan Anak. Tesis. Jakarta: Fakultas Kedokteran Universitas Indonesia; 1991.

14. Dietz WH. Childhood obesity. In: Suskind RM, Lewinter-Suskind, eds. Textbook of pediatric nutrition. 2nd ed. New York: Raven Press; 1993. p. 279-84.

15. Bouchard C. Current understanding of the etiology of obesity: genetic and nongenetic factors. Am J Clin Nutr 1991: 53:1561s-5s.

16. Ravussin E, Swinburn BA. Pathophysiology of obesity. Lancet 1992; 340:404-8.

17. Dietz WH. Critical periods in childhood for the development of obesity. Am J Clin Nutr 1994; 59:955-9.

18. Brook CGD. Evidence for a sensitive period in adipose-cell replication in man. Lancet $1972 ; 23: 624-7$.

19. Faust IM. Adipose tissue growth and obesity. In: Falkner F, Tanner JM, penyunting. Human growth, a comprehensive treatise. 2nd ed. New York: Plenum Press; 1986. p. 61-73.

20. Susulic VS, Lowell BB. Brown adipose tissue and the regulation of body fat stores. Curr Opin Endocrinol Diabetes 1996;3:44-50.

21. Smith SR. The endocrinology of obesity. Endocrinol Metab Clin North Am 1996;25:921-41.

22. Sudiyanto. Tumbuh kembang anak. In: Marsetio M, Tjokronegoro A, eds. Membina anak dalam mencapai cita-citanya. Jakarta: BP FKUI ; 1991. p. 1-13.

23. Alatas H, Karyomanggolo WT, Musa DA, Boediarso A, Oesman IN. Desain penelitian: pandangan umum. In: Satroasmoro S, Ismael S, eds. Dasar-dasar metodologi penelitian klinis. Jakarta: Binarupa Aksara; 1995. p. 52-65.

24. Samsudin. Penilaian keadaan gizi dan pertumbuhan: cara, kegunaan, dan keterbatasannya. In: Samsudin, Nasar SS, Sjarif DR, eds. Masalah gizi ganda dan tumbuh kembang anak. Naskah lengkap Pendidikan Kedokteran Berkelanjutan Ilmu Kesehatan Anak XXXV; Jakarta 11-12 Agustus 1995. Jakarta: Binarupa Aksara; 1995. p. 149-58.

25. Neumann CG. Obesity in pediatrics practice: obesity in preschool and school-age children. Pediatr Clin N Am 1977; 24:117-23.

26. Broussard BA, Johnson A, Himes JH, et al. Prevalence of obesity in American Indians and Alaska natives. Am J Clin Nutt 1991; 53:5355-425.

27. Byers T. The epidemic of obesity in American Indians. AJDC 1992; 146:285-6.

28. Pudjiadi S. Ilmu gizi klinis pada anak. 2nd ed. Jakarta: Balai Penerbit FKUI; 1993. p. 139-47.

29. Tracey VV, De NC, Harper JR. Obesity and respiratory infection in infants and young children. BMJ 1971; 1:16-18.

30. Gidding SS, Bao W, Srinivasan SR, Berenson GS. Effects of secular trends in obesity on coronary risk in children: the Bogalusa heart study. J Pediatr 1995; 127:868-74.

31. Burns TL, Moll PP, Lauer RM. Increased familial cardiovascular mortality in obese schoolchildren: the Muscatin ponderosity family study. Pediatrics 1992; 89:262-8.

32. Rames LK, Clarke WR, Connor WE, et al. Normal blood presure and the elevation of sustained blood pressure elevation in childhood: the Muscatin study. Pediatrics 1978; 61:245-51.

33. Barness LA. Nutrition and nutritional disorder: Obesity. In: Behrman RE, ed. Nelson textbook of pediatric. 14th ed. Philadelphia: Saunders; 1992. p. 133-4.

34. Moussa MAA, Skaik MB, Selwanes SB, et al. Contribution of body fat pattern to blood pressure level in school children. Eur J Clin Nutr 1994; 48:587-90. 
35. Fomon SJ, Filer W, Thomas LN, Anderson TA, Nelson SE. Influence of formula concentration on caloric intake and growth of normal infants. Acta Paediatr Scand 1975; 64:172-81.

36. Soedibjo S. Aspek gizi dari pada air susu ibu. In: Suharyono, Suradi R, Firmansyah A, eds. Air susu ibu, tinjauan dari beberapa aspek. Jakarta: BP FKUI; 1992. p. 59-64.

37. Samsudin. Nukleotida dan peranannya dalam makanan bayi. Presented at Pertemuan Ilmiah Bagian Ilmu Kesehatan Anak FKUI, Jakarta, September 21, 1994.

38. Agras WS, Kraemer HC, Berkowitz RI, Hammer LD. Influence of early feeding style on adiposity at 6 years of age. J Pediatr 1990; 116:805-9.

39. Agras WS, Kraemer HC, Berkowitz RI, Korner AF, Hammer LD. Does a vigorous feeding style influence early development of adiposity ? J Pediatr 1987; 110:799-804.

40. Agung G, Nanny S, Anglingsari S. Gemuk lucu tapi merepotkan. Intisari 1997 May 1997; 177-91.

41. Dietz WH, Gortmaker SL. Do we fatten our children at the television set ? Obesity and television viewing in children an adolescents. Pediatrics; 75:807-12.

42. Barness LA, Dallman PR, Anderson H, et al. Nutritional aspects of obesity in infancy and childhood. Pediatrics $1981 ; 68: 880-3$.

43. Garrow JS. Treatment of obesity. Lancet 1992; 340:409-13.

44. Endo H, Takagi Y, Nozue T, et al. Beneficial effects of dietary intervention on serum lipid and apolipoprotein levels in obese children. A.JDC 1992; 146:303-5.

45. Franklin BA, Rubenfire M. Losing weight through exercise. JAMA 1980; 244:377-9.

46. Sargowo D. Studi penelitian lipoprotein (a) $=\mathrm{Lp}$ (a) sebagai faktor risiko dan prediktor penyakit jantung koroner. J Kardiol Indon 1995; 20:121-31.

47. Dwyer T. Hyperlipidemia in children. Hongkong J Paediatr 1995; 1:69-76. 